\title{
Iron Cage Birokrasi Pendidikan: Suatu Analisis Sosiologis
}

\author{
Siti Ikramatoun ${ }^{1}$, Khairul Amin ${ }^{2 *}$, Darwin ${ }^{3}$, Halik $^{4}$ \\ Universitas Syiah Kuala Banda Aceh ${ }^{1}$ \\ Madrasah Aliyah Negeri 1 Pidie 2,3 \\ Universitas Jabal Ghafur Sigli 4 \\ Email: alqonz90@gmail.com ${ }^{2^{*}}$ \\ * corresponding author
}

\begin{abstract}
Abstrak
Artikel ini bertujuan mendeskripsikan birokrasi pendidikan sebagai alat untuk mencapai tujuan penyelenggaraan pendidikan melalui pendekatan kualitatif dengan model studi literatur. Data dalam tulisan ini bersumber dari literatur yang relevan dan pengalaman penulis selama aktif dalam aktivitas pendidikan. Hasil kajian menunjukkan bahwa birokrasi dalam bentuk administrasi pendidikan berubah menjadi "kerangkeng besi" yang membelenggu aktivitas pendidikan itu sendiri. Penyelenggaraan pendidikan kehilangan orientasinya dan berubah menjadi rutinitas seremonial demi memenuhi tuntutan birokrasi. Beragam pelatihan dan peningkatan kapasitas maupun kompetensi guru dalam dunia pendidikan telah dilakukan, namun belum mampu mengubah wajah pendidikan secara signifikan. Kontrol birokrasi membuat para guru "terlihat" sedang mengembangkan kompetensinya, padahal sejatinya sedang memenuhi tuntutan birokrasi. Untuk itu, pendidikan harus keluar dari "jerat birokrasi" dengan cara mereduksi semua aspek administratif yang membelenggu aktivitas mulia pendidikan. Birokrasi adalah hasil ciptaan manusia, maka seharusnya birokrasi tunduk pada manusia dan bukan manusia yang tunduk pada kehendak birokrasi.
\end{abstract}

Kata kunci: birokrasi; pendidikan; kerangkeng besi

\section{Iron Cage Educational Bureaucracy: A Sociological Analysis}

\begin{abstract}
This article aims to describe the education bureaucracy as a tool to achieve the objectives of education through a qualitative approach to the literature study model. The data in this paper is sourced from relevant literature and the author's experience while active in educational activities. The results of this study indicate that the bureaucracy in the form of educational administration has changed to an iron cage that shackles the educational activity itself. The delivery of education loses its orientation and turns into ceremonial routines to meet the demands of the bureaucracy. Various training, capacity building, and teacher competence have been done, but they have not significantly changed the face of education. Iron cage bureaucracy makes teachers "appear" to be developing their competence, but in fact, they are meeting the demands of the bureaucracy. Education must come out of the iron cage bureaucracy by reducing all administrative aspects that bind the noble activities of education. Bureaucracy is a human creation, so bureaucracy should be subject to humans and not humans who are subject to the will of the bureaucracy.
\end{abstract}

Keywords : bureaucracy; education; iron cage 


\section{LATAR BELAKANG}

Pendidikan secara etimologi berasal dari kata "didik" yang berarti ajaran, pimpinan, bimbingan. Dalam Bahasa Inggris disebut dengan istilah education yang berasal dari kata educate yang berarti mendidik, dan dalam bahasa Arab biasa disebut dengan istilah tarbiyyah yang asal kata rabba, yang berarti tumbuh dan berkembang. Naquib Al Attas dalam Syaiful (2018) ketika menjelaskan definisi pendidikan ia lebih memilih menggunakan istilah ta'dib karena menurutnya istilah ta'dib lebih mencakup unsur-unsur yang ada dalam pendidikan yakni pengetahuan ( $\mathrm{ilm}$ ), pengajaran (talim) dan pengasuhan (tarbiyah). Dalam Undang-undang Sistem Pendidikan Nasional No. 20 tahun 2003, pendidikan didefinisikan sebagai "usaha sadar dan terencana untuk mewujudkan suasana belajar dan proses pembelajaran agar peserta didik secara aktif mengembangkan potensi dirinya untuk memiliki kekuatan spiritual keagamaan, pengendalian diri, kepribadian, kecerdasan, akhlak mulia, serta ketrampilan yang diperlukan dirinya, masyarakat, bangsa dan negara".

Sejak dahulu pendidikan menjadi sesuatu yang penting dalam kehidupan sosial masyarakat. Institusi pendidikan menjadi salah satu alat ukur utama untuk menentukan tingkat kemajuan dan kemunduran masyarakat. Jika pendidikan berkualitas, maka akan lahir masyarakat dan bangsa yang juga berkualitas, dan pada gilirannya dapat mengantarkan pada kehidupan yang lebih maju. Demikian pula sebaliknya, ketika pendidikan tidak berkualitas, maka akan lahir masyarakat yang kehidupannya jauh dari standar hidup bangsa yang cerdas dan berkualitas. Itulah mengapa para pendiri bangsa ini menetapkan salah satu amanah dalam Undang-Undang Dasar 1945 yaitu "mencerdaskan kehidupan bangsa". Hanya bangsa yang cerdas yang dapat mengantarkan masyarakatnya pada kesejahteraan dan kemakmuran (Solihin, 2015).

Melihat begitu pentingnya pendidikan, maka tidak heran ketika Amerika tertinggal dari Uni Soviet dalam bidang teknologi ruang angkasa tahun 1957, J.F. Kennedy kala itu bertanya "What's wrong with American classroom?". Pertanyaan sederhana ini kemudian memicu lahirnya pembaharuan pendidikan di Amerika masa itu. Demikian pula dengan Kaisar Jepang sesaat setelah bom atom yang meluluh lantakan NagashakiHiroshima, dengan penuh kekhawatiran langsung bertanya; "berapa jumlah guru yang masih hidup". Kemudian Ho Chi Min (bapak pendidikan Vietnam) juga pernah mengatakan bahwa: no teacher no education; no education, no economic and social development (Solihin, 2015). Demikian pula halnya dengan Indonesia, mengingat begitu pentingnya pendidikan maka penyelenggaraan pendidikan menjadi salah satu prioritas utama di negeri ini dengan alokasi anggaran yaitu 20\% dari total APBN. Pada tahun 2019 anggaran pendidikan naik Rp 48,4 triliun dari tahun sebelumnya (Syambudi, 2019).

Besaran anggaran pendidikan yang dialokasikan pemerintah menunjukkan bahwa sektor pendidikan menjadi sektor vital dan menjadi perhatian utama pemerintah Indonesia. Namun dalam perjalanannya meski asas desentralisasi pendidikan telah diberlakukan pasca reformasi dan anggaran yang diberikan sangat besar, ternyata tidak secara otomatis dapat mengangkat harkat hidup masyarakat Indonesia dalam hal pendidikan. (Fauzie, 2018) mengatakan masih banyak ditemukan masalah dalam dunia pendidikan, mulai dari hal teknis hingga substantif, dari infrastruktur hingga mutu pendidikan yang rendah. Salah satu masalah mendasar dalam pendidikan di Indonesia menurut Masduki (2012) adalah dehumanisasi dalam dunia pendidikan yang mengakibatkan praktik pengelolaan sektor pendidikan menjadi sangat birokratis. akibatnya pendidik maupun peserta didik menjadi korban sistem birokrasi. Hal tersebut 
dapat dilihat mulai dari jam belajar, waktu mengajar, materi ajar, pemberian nilai, akreditasi sekolah, hingga manajemen sekolah yang penuh dengan berbagai aturan birokratis yang "memaksa". Dunia pendidikan terjebak pada serangkaian aturan yang secara perlahan menjauh dari fungsi utama pendidikan sebagai wadah untuk mengembangkan potensi pendidik dan peserta didik untuk memiliki kekuatan spiritual keagamaan, pengendalian diri, kepribadian, kecerdasan, akhlak mulia, serta ketrampilan yang diperlukan dirinya, masyarakat, bangsa dan negara.

Birokrasi dalam penyelenggaraan pendidikan tentu sesuatu yang mutlak ada dan menjadi salah alat untuk mencapai tujuan pendidikan itu sendiri. Melalui birokrasi, arah dan tujuan pendidikan diatur sedemikian rupa, termasuk hal-hal apa saya yang boleh dan tidak boleh dilakukan dalam penyelenggaraan pendidikan. Oleh karena itu, tulisan ini bertujuan untuk mendeskripsikan lebih lanjut tentang bagaimana birokrasi pendidikan diimplementasikan, terutama terkait praktik birokrasi di dunia pendidikan. Karena birokrasi sebagai cara yang paling rasional dan efisien untuk mencapai suatu tujuan menurut sering kali terjebak pada sesuatu yang disebut Weber sebagai "kerangkeng besi atau iron cage" yaitu praktik birokrasi yang kehilangan substansinya sebagai "alat bantu" untuk mencapai tujuan $\mathrm{Hal}$ ini dianggap penting karena jika birokrasi dalam bentuk administrasi pendidikan berubah menjadi "kerangkeng besi/iron cage" maka dunia pendidikan akan terbelenggu oleh aturan-aturan yang diciptakan dalam birokrasi itu sendiri.

\section{METODE PENELITIAN}

Artikel ini menggunakan metode kualitatif dengan model studi literatur yaitu suatu kegiatan mendalami, menelaah dan mengidentifikasi pengetahuan yang didasarkan pada hasil penelitian atau kajian sebelumnya (Fitrah \& Luthfiyah, 2018:138). Menurut Creswell (2009) studi literatur merupakan upaya yang dilakukan peneliti untuk memperoleh dan menghimpun segala informasi tertulis yang relevan dengan masalah yang diteliti. Oleh karena itu, data dalam tulisan ini bersumber kajian literatur yang relevan dan juga bersumber dari pengalaman penulis selama terlibat aktif dalam dunia pendidikan. Dengan menggunakan metode ini penulis mengumpulkan berbagai literatur yang berkaitan dengan dinamika pendidikan, perspektif teoritik Weber tentang kerangkeng besi dan birokrasi, kemudian menarik korelasinya dengan kondisi pendidikan saat ini. Selain itu, penulis juga merefleksikan pengalam penulis selama terlibat dalam dunia pendidikan sesuai dengan kajian literatur yang dilakukan.

\section{HASIL DAN PEMBAHASAN \\ Kurikulum Pendidikan di Indonesia}

Kurikulum merupakan inti dari aktivitas pendidikan dan sekaligus menjadi pedoman penyelenggaraan pendidikan. Isi kurikulum adalah hasil kajian mendalam dalam rangka upaya pencapaian tujuan pendidikan nasional. Kurikulum disusun sedemikian rupa dengan tujuan utama untuk mewujudkan pendidikan nasional yang sesuai dengan kebutuhan dan perkembangan peserta didik. Kemudian juga sesuai dengan kebutuhan pembangunan nasional, lingkungan, perkembangan ilmu pengetahuan dan teknologi serta sesuai dengan jenjang masing-masing satuan pendidikan. Atas dasar inilah kemudian kurikulum menjadi sangat penting dan besar pengaruhnya dalam menciptakan generasi bangsa (Ritonga \& Basri, 2016). 
Kurikulum pendidikan telah berubah berkali-kali sesuai dengan kebutuhan dan perkembangan zaman. Sejak kemerdekaan Indonesia tahun 1945, kurikulum pendidikan nasional telah berulang kali mengalami perubahan. Di mulai pada tahun 1947, kemudian tahun 1952, lalu 1964, 1968, 1975, 1984, 1994, 2004, 2006 dana yang terbaru adalah kurikulum 2013 atau dikenal dengan istilah K13. Menurut Alhamuddin (2014) perubahanperubahan kurikulum yang terjadi di Indonesia merupakan dampak dari perubahan sistem politik, sistem sosial budaya, ekonomi, dan perkembangan teknologi yang berlangsung dari tahun ke tahun. Secara normatif perubahan kurikulum dalam pengertian sebagai seperangkat rencana pendidikan pada dasarnya memang bersifat dinamis dan sesuai dengan tuntutan perubahan yang terjadi di masyarakat. Namun dari sekian banyak perubahan yang terjadi tampak bahwa determinan paradigma politik dan kekuasaan kuat mewarnai dan mempengaruhi sistem pendidikan Indonesia selama ini. Artinya, sistem politiklah yang dominan menentukan bagaimana pendidikan diselenggarakan. Kecenderungan inilah yang kemudian melahirkan istilah "ganti menteri ganti kurikulum". Muatan-muatan politis, nilai, ideologi, maupun tujuan-tujuan tertentu yang diinginkan penguasa termanifestasi dalam kerangka kurikulum (Alhamuddin, 2014).

Pada awal masa kemerdekaan di bawah orde lama, regulasi nasional yang mengatur pendidikan disesuaikan dengan mempertahankan kemerdekaan. Pada masa ini menurut (Afriantoni, 2013) pendidikan yang dipraktikkan dipengaruhi oleh Belanda dan berlangsung hingga tahun 1965. Kemudian setelah tahun 1966 ketika rezim orde baru berkuasa, kiblat pendidikan Indonesia lebih banyak meniru model pendidikan Amerika yang memosisikan pendidikan sebagai salah satu instrumen pembangunan. Pada masa ini penyelenggaraan pendidikan sangat sentralistik dan lembaga pendidikan bergantung pada keputusan birokrasi, sehingga sering kali produk kebijakan pendidikan tidak sesuai dengan kondisi yang diharapkan oleh pelaksana pendidikan di tingkat sekolah yang ada di Indonesia. Lebih lanjut, menurut Masduki (2012) ada tiga ciri utama sistem pendidikan era Orde Baru yang masih mewarnai sistem pendidikan hingga saat ini, yaitu (1) sistem kaku dan sentralistik; (2) praktik korupsi, kolusi, nepotisme dan kronisme; (3) tidak berorientasi pada pemberdayaan masyarakat. Akibatnya, tujuan pendidikan untuk mencerdaskan berubah menjadi praktik-praktik yang memberatkan masyarakat untuk memperoleh pendidikan yang berkualitas.

Salah satu hasil dari dunia pendidikan model orde baru tersebut menurut Hasnah (2012) adalah berkembanglah manusia yang dengan mentalitas pekerja di mana output dunia pendidikan diarahkan untuk menjadi pekerja/buruh. Peserta didik dianggap berhasil ketika mereka mengerjakan sesuai dengan apa yang di perintahkan dan siap diperlakukan secara seragam. Sistem atau model pendidikan seperti ini merupakan ciri khas yang melekat pada era revolusi industri 3.0, dimana para peserta didik dipersiapkan untuk masuk ke dunia industri yang serba birokratis dan terstruktur. Secara positif sistem pendidikan yang seperti ini sangat bermanfaat bagi pengembangan sektor ekonomi pembangunan yang pada masa itu memang menjadi fokus dari pemerintah atau penguasa. Namun dampak negatifnya adalah pendidikan hanya mentransfer pengetahuan yang bersifat text book dengan output pendidikan yang bersifat materialistik, individualistik dan konsumtif (Hasnah, 2012).

Implementasi kurikulum yang selalu berubah sejak zaman kemerdekaan memberi kesan tentang gagalnya dunia pendidikan. Menurut Miller \& Seller dalam Alhamuddin (2014) sedikitnya ada empat faktor penyebab utama mengapa hal tersebut 
terjadi. Pertama faktor birokrasi, yaitu harapan dan perlakuan yang berlebihan pada peran kurikulum dan menomor duakan unsur pendidik/guru. Kedua faktor kurikulum, yaitu tidak sesuainya realitas sosial dan tuntutan perubahan di masyarakat akibat lemahnya dasar-dasar filosofis dan psikologis dalam penjabaran kurikulum. Ketiga faktor pelaksana kurikulum, yaitu lemahnya profesionalisme dan tingkat kompetensi pendidik/guru, dan terakhir faktor ekosistem pendidikan, yaitu lemahnya dukungan sosial dan minimnya infrastruktur pendidikan, terutama sekolah-sekolah yang ada di daerah.

Keempat faktor saling berkaitan dan menjadi satu kesatuan yang mengakibatkan gagalnya setiap perubahan kurikulum ketika diimplementasikan. Guru dituntut untuk berperan sebagai pelaksana semata, meski dengan pemahaman konseptual yang minim (Alhamuddin 2014:57). Tumpukan administrasi guru yang diatur sedemikian rupa dan menjadi suatu kewajiban semakin memperparah kondisi tersebut dan secara perlahan menghilangkan substansi pelaksaan kurikulum. Perlahan tapi pasti, implementasi kurikulum di lapangan berubah menjadi ajang untuk memenuhi administrasi yang dibebankan, bukan untuk memenuhi tuntutan dari kurikulum itu sendiri. Guru dengan semua perlengkapannya, kegiatan-kegiatan pendukungnya, terjebak pada tuntutan pemenuhan administrasi.

Ketika memasuki Era revolusi industri 4.0 terjadi perubahan terhadap cara berpikir dan perspektif terhadap dunia pendidikan. Perubahan yang dibuat bukan hanya cara mengajar, tetapi jauh lebih penting adalah perubahan dalam perspektif konsep pendidikan itu sendiri. Oleh karena itu, pengembangan kurikulum saat ini dan masa depan harus melengkapi kemampuan siswa dalam dimensi pedagogi, kemampuan hidup, kemampuan untuk hidup bersama (kolaborasi) dan pemikiran kritis dan kreatif. Mengembangkan soft skill dan keterampilan, serta keterampilan tidak terlihat yang tidak terkait dengan bidang pekerjaan dan akademik tertentu. Namun, berguna dalam berbagai kerja seperti keterampilan interpersonal, hidup bersama, kemampuan menjadi warga negara yang berpikiran global, dan literasi media dan informasi. Pengembangan kurikulum harus diarahkan dan membentuk siswa yang siap menantang era revolusi industri dengan penyesuaian pada bidang Sains, Teknologi, Teknik, dan Matematika (STEM), juga berkarakter. Reorientasi Kurikulum yang berfokus pada pembelajaran berbasis TIK, internet, big data dan komputerisasi, serta kewirausahaan dan magang, perlu menjadi kurikulum yang diperlukan untuk menghasilkan pengajaran yang terlatih di bidang literasi informasi, teknologi literasi, dan literasi manusia (Lase, 2019).

\section{Iron Cage}

Iron cage adalah istilah atau konsep yang dikembangkan oleh sosiolog Jerman Max Weber. Konsep ini istilah yang digunakan untuk menggambarkan efek negatif dari rasionalitas masyarakat modern yang terwujud dalam bentuk birokrasi. Kajian Weber tentang birokrasi telah berhasil menstimulasi aliran utama penelitian dalam ranah birokrasi berfokus pada fungsi dan disfungsi birokrasi. Kemudian gagasannya tentang organisasi formal dalam bentuk birokrasi sebagai 'kerangkeng besi' menjadi salah satu tema utama dari karyanya. (Greenwood \& Lawrence, 2005:494)

Konsep teoritik tentang kerangkeng besi dikembangkan oleh Max Weber dalam salah satu karyanya yang berjudul The Protestant Ethic dan Spirit of Capitalism pada tahun 1905. Dalam buku ini, Weber menyebutkan tentang hubungan antara "etika Protestan" dan "kapitalisme" berhasil membentuk masyarakat secara birokratis dan 
ekonomis yang kemudian meningkatkan rasionalisasi dalam kehidupan sosial. Dengan birokrasi yang terbentuk akibat peningkatan rasionalitas berwujud kontrol dan perhitungan rasional menjatuhkan orang ke dalam sistem yang diciptakannya. Akibatnya tindakan bebas manusia dan masyarakat menjadi semakin terbatas dan dengan sistem hierarkis yang ada dalam birokrasi membuat orang dilahirkan dalam sangkar yang tidak dapat mereka lepaskan. Artinya, pencipta menjadi budak ciptaannya sendiri. (Tekin, 2017)

Iron cage birokrasi atau kerangkeng besi birokrasi dalam kehidupan modern menjadi semakin dominan. Menurut Weber birokrasi mencapai posisi dan peran dominan dalam masyarakat modern karena tiga alasan strategis. Pertama, keunggulan teknisnya atas semua bentuk lain dari organisasi dan manajemen administratif memberikannya keuntungan luar biasa dalam memenuhi kebutuhan fungsional dan persyaratan operasional ekonomi dan pemerintahan modern. Kedua, kekuatan budayanya sebagai kerangka kerja kognitif di mana musyawarah dan perhitungan rasional berhasil memberikan tingkat legitimasi dan penerimaan yang tak tertandingi. Ketiga kemampuan birokrasi memadukan kekuatan administratif, budaya, dan politik dalam satu bentuk dan mekanisme organisasi dan sekaligus menegaskan status kelompok dan kelas sosial (Gay, 2005:119).

Eksisnya birokrasi di masyarakat modern menurut Weber menghasilkan manfaat material dan sosial jangka panjang yang cukup besar. Namun di sisi lain, birokrasi membangun "kerangkeng besi" yang seperti penjara dan membatasi orang-orang yang ada di dalamnya. Hierarki birokrasi dapat mengendalikan sumber daya, sedangkan pekerja atau orang yang ada dalam hierarki terbawah tidak dapat mengendalikan sumber daya dan sekaligus tidak memiliki sumber daya. Alhasil, birokrasi terperangkap pada "kerangkeng besi" di mana masyarakat dibatasi oleh perintah hierarkis (Tekin, 2017). Oleh sebab itu, meski banyak kajian yang memuji birokrasi dalam bentuk administrasi sebagai cara 'rasional' untuk menjalankan suatu organisasi. Namun, ada pula yang menganggap birokrasi sebagai penghambat kreativitas, mendorong demotivasi dan menjadi penyebab tekanan pada individu dalam suatu organisasi (Yuksel, 2014).

\section{Birokrasi}

Sejak abad 19 birokrasi telah menjadi aktor yang sangat penting dalam kehidupan manusia. Dari lahir hingga meninggal, seorang manusia yang hidup di dunia modern akan selalu berurusan dengan birokrasi karena kehidupan di era modern menempatkan birokrasi pada posisi yang sangat penting dan sekaligus menjadi institusi yang paling dibutuhkan (the more important and dominant institution). Tidak mungkin proses kehidupan masyarakat modern berlangsung tanpa adanya birokrasi (Setiyono, n.d.:11). Termasuk pula dunia pendidikan yang segala aspeknya bersentuhan langsung dengan birokrasi yang berupa administrasi pendidikan. Administrasi tersebut mencakup semua kegiatan yang bersifat teknis ketatausahaan yang melekat dan menjadi satu kesatuan dalam proses penyelenggaraan pendidikan (Hadijaya, 2012).

Terdapat banyak kajian yang memuji birokrasi dalam bentuk administrasi sebagai cara rasional untuk menjalankan suatu organisasi. Namun, di sisi lain, ada pula yang menganggap birokrasi sebagai penghambat kreativitas, mendorong demotivasi dan menjadi penyebab tekanan pada individu dalam suatu organisasi (Yuksel, 2014). Birokrasi sering diartikan sebagai organisasi para pejabat yang tersusun secara hierarkis 
yang diangkat untuk melaksanakan tujuan-tujuan publik tertentu (Suwarno, 2008). Secara bahasa, istilah birokrasi berasal dari kata bureaucracy, gabungan dari akar kata bureau dan cracy. Bureau berarti "meja tulis tempat pejabat biasanya bekerja", dan cracy, berarti aturan (Suwarno, 2008). Menurut Hariandja (1999), dalam konteks kehidupan sosial, birokrasi dapat dipahami melalui tiga pendekatan yaitu: pertama, sebagai organisasi yang bersifat umum. Kedua, sebagai Administrasi, khususnya Administrasi Negara dimana birokrasi merupakan kebijakan yang menjalankan fungsifungsi maupun tugas-tugas yang sifatnya administratif dari Negara. Ketiga, sebagai manifestasi dari kehadiran negara dalam masyarakat secara langsung.

Secara ideal, konsep birokrasi biasanya selalu disandarkan pada pemikiran Max Weber tentang birokrasi ideal/rasional. Hal ini sebagaimana dikutip oleh Wright dalam Suwarno (2008), yang menyatakan bahwa birokrasi ideal memiliki ciri utama yaitu: (1) terdapat pembagian tugas yang jelas, (2) terstruktur, yaitu memiliki struktur kewenangan yang hierarkis dengan batas-batas tanggung jawab yang jelas, (3) hubungan yang terjalin antar anggota yang bersifat impersonal, (4) sistem rekrutmen didasarkan pada kecakapan teknis, dan (5) ada pemisahan yang jelas antara urusan publik dengan urusan pribadi yang akan menjamin pelaksanaan tugas secara efisien.

Di Indonesia, pada awal kemerdekaan peran birokrasi belum begitu kuat karena pada masa Orde Lama energi pemerintah dan rakyat banyak digunakan untuk mempertahankan kemerdekaan dari Belanda yang ingin menjajah kembali Indonesia. Ketika memasuki era Orde Baru di bawah kendali Presiden Suharto, birokrasi mulai mendapatkan porsinya karena birokrasi dianggap dapat menjadi mesin yang efektif bagi pertumbuhan ekonomi negara yang sedang terpuruk saat itu. Hingga saat ini birokrasi berperan sangat efektif dalam menjalankan program-program administrasi dan ekonomi pemerintah, termasuk dalam dunia pendidikan (Suwarno 2008:284). Salah satu efek negatif yang muncul dari birokrasi ini adalah ketidakmampuan individu mengontrol birokrasi yang mereka ciptakan untuk mencapai tujuan. Akhirnya, birokrasi yang pada mulanya ditujukan untuk sebagai alat kontrol sistem, pada akhirnya berubah menjadi penguasa atas perilaku manusia yang ada dalam sistem tersebut. Manusia dengan birokrasi yang diciptakannya terjebak pada "kerangkeng besi" yang dalam istilah Weber disebut dengan iron cage.

Meskipun weber menyatakan akan hadirnya kerangkeng atau kerangkeng besi birokrasi, namun Weber juga mengakui bahwa kehadiran birokrasi dalam kehidupan masyarakat juga memberikan sisi posistif, terutama birokrasi yang rasional, walaupun birokrasi rasional juga tidak menutup kemungkinan akan lahirnya sisi negatif. Sisi negatif tersebut adalah terjadinya pembatasan kebebasan individu akibat sistem kontrol yang hierarkis dalam birokrasi. Keseragaman dalam tindakan dan prosedur yang rasional dari birokrasi akan dapat menghambat spontanitas, kreativitas, dan inisiatif individu, sehingga manusia akan berbeda pada situasi yang dia sebut sebagai kerangkeng besi. Di samping itu, Weber juga mengkhawatirkan aktivitas dan loyalitas yang didasarkan pada formalitas peraturan yang bersifat impersonal akan mengakibatkan manusia menjalankan tugas tidak dengan sepenuh hati, tanpa penghayatan yang baik, serta memproduksi pegawai yang tanpa motivasi. Yang lebih mengkhawatirkan lagi adalah, pada masa krisis, sistem birokrasi rasional tidaklah efektif karena birokrat rasional dilatih untuk mengikuti prosedur, perintah, dan menyelenggarakan tugas-tugas rutin daripada mengambil inisiatif untuk merespons terjadinya krisis dan perubahan. Dengan demikian, apabila krisis terjadi pada masyarakat, di mana peraturan yang ada mungkin tidak sesuai 
lagi, kondisi tidak dapat diprediksi, dan fasilitas kerja tidak dapat digunakan, birokrasi tidak mampu berpikir dan bertindak secara tepat menghadapi perubahan yang terjadi (Masniyah, 2018:24).

\section{Iron Cage Birokrasi Pendidikan}

Rasionalisasi birokrasi yang berubah menjadi "kerangkeng besi" sering kali dibungkus oleh rasionalitas. Demikian pula dengan dunia pendidikan saat ini dimana birokrasi merupakan sesuatu yang mutlak ada. Tidak adakan ada penyelenggaraan pendidikan tanpa birokrasi. Tentu hal ini sesuatu yang baik, namun jika kehadiran birokrasi ditengah-tengah pendidikan malah menghambat kreativitas dan membatasi tindakan individu yang ada dalam dunia pendidikan tentu kehadiran birokrasi tersebut harus kembali dipertanyakan. Karena jika penyelenggara pendidikan terjebak dalam suatu rutinitas yang dikontrol oleh birokrasi, maka cita-cita membangun manusia yang memiliki otonomi dalam bidang pendidikan menjadi tidak tercapai. Implementasi birokrasi yang menghambat aktivitas substansial dunia pendidikan hanya akan menjauhkan tujuan mulia pendidikan sebagai alat pembebasan dari kemiskinan dan kebodohan.

Ada beberapa fenomena yang mengindikasikan bahwa implementasi birokrasi dalam dunia pendidikan berubah menjadi "belenggu" pendidikan itu sendiri. Salah satunya adalah guru atau pendidik di dunia pendidikan dipenuhi dengan aturan-aturan yang bersifat rutinitas dalam menjalankan roda pendidikan. Mulai jam masuk hingga pulang, mulai dari cara membuat rancangan pembelajaran, implementasi hingga penilaian semua diatur dan harus sesuai dengan aturan. Dan lembaga serta pendidik akan "dianggap" berhasil selama mampu mengikuti apa yang diperintahkan dalam aturan tersebut meski proses implementasinya sarat akan manipulasi, karena yang terpenting adalah tuntutan administrasi terpenuhi. Ada banyak standar yang harus terpenuhi, mulai dari standar isi, standar kompetensi, penilaian, proses, pengelolaan, sarana prasarana, tenaga kependidikan hingga pembiayaan (lihat, BNSP). Penulis tentu menyadari bahwa semua aturan tersebut pada dasarnya dibutuhkan oleh dunia pendidikan saat ini, tetapi pada tataran implementasinya juga harus melihat aspek sosiologis dari lembaga, pendidik, peserta didik dan masyarakat. Karena jika tidak memperhatikan hal-hal tersebut, sekumpulan aturan birokrasi itu hanya akan menjadi "belenggu" yang kemudian mengekang lembaga pendidikan dan semua usaha dalam menjalankan roda pendidikan hanya akan diarahkan untuk memenuhi kehendak birokrasi dan administrasi yang terkadang ahistoris, tidak sesuai dengan realitas pendidikan yang berlangsung. Dengan aturan yang sangat ketat melalui rezim birokrasi pemerintahan membuat para pendidik harus menyibukkan untuk memenuhi tuntutantuntutan administratif yang mengalienasi mereka dari tugas utama pendidikan. Dalam bahasa Karl Marx Birokrasi menjadi kekuatan otonom dan opresif yang dirasakan masyarakat sebagai entitas yang misterius, asing, dan berjarak. Meski sehari-hari birokrasi meregulasi kehidupan manusia, namun manusia sendiri tak mampu mengontrol dan memahaminya dengan jernih. Dalam bahasa yang berbeda, Marx menyebutkan bahwa birokrasi adalah "lingkaran ajaib yang tak seorang pun dapat keluar darinya".

Harus diakui, kehadiran birokrasi dalam dunia pendidikan memang merupakan sesuatu yang mutlak ada. Birokrasi sangat dibutuhkan dalam konteks dunia modern saat ini, terlebih ketika dunia pendidikan memasuki era revolusi industri 4.0. Sejatinya 
kehadiran birokrasi tersebut dimaksudkan agar dapat memudahkan urusan-urusan terkait administrasi pendidikan yang ujung-ujungnya mempermudah penyelenggaraan sistem pendidikan untuk menciptakan generasi yang cerdas dan berdaya saing. Namun saat ini yang lebih menonjol dengan adanya birokrasi adalah aturan-aturan yang sangat banyak dan cenderung menghambat dunia pendidikan untuk mencapai yang dicitacitakannya. Kita dapat melihat misalnya; seperangkat aturan administratif yang membebani tenaga pengajar mulai dari urusan kelembagaan hingga urusan pembelajaran yang kemudian malah berakibat pada hilangnya profesionalisme dan kompetensi sang pendidik. Demi memenuhi tuntutan administrasi pendidikan, para pendidik menjadi sangat sibuk hingga lupa mengupgrade kompetensinya. Akibatnya materi pembelajaran yang diajarkan menjadi tidak kontekstual sehingga peserta didik pun tidak meningkat kompetensinya.

Lain halnya misalkan dengan lembaga-lembaga pendidikan non struktural yang tidak terlalu terikat dengan "rezim birokrasi" atau lembaga yang fokus pada pengembangan materi pembelajaran serta kegiatan belajar mengajar seperti bimbingan belajar (bimbel). Kita dapat melihat output dari bimbel jauh lebih memiliki pemahaman materi yang kuat dan lebih siap menghadapi berbagai ujian dari pada peserta didik yang hanya mengandalkan kegiatan belajar mengajar di sekolah. Salah satu penyebabnya adalah para pendidik yang ada di lembaga non struktural seperti bimbel tidak terlalu terikat dengan birokrasi lembaga, mereka hanya fokus pada pengajaran materi. Itulah kenapa kemudian para lulusan sekolah kita saat ini masih harus mengambil les tambahan ke bimbel untuk melanjutkan ke perguruan tinggi meski telah lulus di lembaga sekolah. Tidak jarang pula kita temui sekolah-sekolah yang bekerja sama dengan lembaga bimbel untuk memberikan kelas-kelas tambahan dalam mempersiapkan diri menghadapi ujian. Sedangkan para guru yang ada fokus pada pemenuhan persyaratan administrasi yang diminta oleh lembaga. Bahkan fenomena yang umum saat ini dapat disaksikan adalah menjamurnya bimbingan-bimbingan belajar di sekitar lembaga pendidikan formal.

Guru sebagai agen penting pendidikan sebenarnya memiliki peluang yang amat besar untuk mengubah kondisi masyarakat jika guru tersebut bekerja sesuai dengan asas profesionalismenya dimana para guru tersebut memiliki landasan pengetahuan yang kuat, kompetensi individual, memiliki sistem seleksi dan sertifikasi, kesadaran profesional yang tinggi dan lain sebagainya. Tetapi dalam suatu birokrasi pendidikan di bawah politik kurikulum misalnya, profesionalitas seorang guru atau pendidik direduksi menjadi kepatuhan atas aturan-aturan birokrasi yang ada (Suyanto, 2006: 1). Akibatnya, kekuatan seorang pendidik sebagai agen pendidikan turut direduksi hanya pada kemampuan mereka memenuhi harapan birokrasi. Guru kemudian terpaksa harus tunduk meskipun lembaga pendidikan tempatnya bernaung atau peserta didik mereka tidak memiliki kapasitas sebagaimana yang diharapkan dari birokrasi yang ada. Sebutlah misalnya dengan sistem akreditasi lembaga pendidikan yang menuntut para guru harus menyibukkan diri mereka dengan penyusunan borang beserta seluruh komponen administratifnya yang kemudian mengorbankan peserta didik dari proses belajar mengajar. Atau misalnya mark up nilai yang terpaksa harus dilakukan demi memenuhi aturan birokrasi agar lembaga pendidikan mendapatkan akreditasi yang baik padahal kompetensi siswanya belum mampu memenuhinya. Hal-hal seperti ini menjadi rutinitas yang kemudian dirayakan dalam seremonial-seremonial sambil meninggalkan substansi dari penyelenggaraan pendidikan 
Contoh lain misalnya; hasil penelitian yang dilakukan oleh Mulyono dkk (dalam Afriantoni 2013:280) yang menunjukkan bahwa birokratisasi dalam sistem pendidikan sebenarnya tidak atau belum berdampak secara signifikan terhadap kompetensi atau mutu pendidikan itu sendiri. Dengan sertifikasi, para pendidik di sekolah belum mampu mengaplikasikan empat komponen tentang standar nasional pendidikan. Pemberian teori belajar dan penggunaan bahasa Indonesia yang baik pun belum mampu sepenuhnya dilakukan oleh para guru dan tidak mengalami peningkatan meskipun setelah adanya sertifikasi. Kompetensi kepribadian guru juga belum mengalami peningkatan yang signifikan untuk lebih berkomitmen dalam menjalankan tugasnya sebagai guru yang profesional. Bahkan yang cukup mengejutkan adalah bahwa kinerja guru dinilai meningkat hanya saat guru-guru belum lolos sertifikasi dan setelah mendapatkan sertifikasi kinerja guru menjadi menurun seperti para guru menjadi enggan untuk mengikuti seminar atau pelatihan untuk peningkatan kualitas diri. Padahal sebelum mendapat sertifikasi, para guru menjadi lebih sering mengikuti pelatihan untuk meningkatkan kualitas diri. Konteks seperti ini dalam istilah Graber disebut dengan Structural Stupidity yakni kebodohan dari para birokrat dalam memaksakan praktik birokrasi ketika seluruh masyarakat sudah terjebak di dalam apa yang Weber konseptualisasi sebagai iron cage (Bagaskara, 2016)

Kondisi pendidikan dengan segudang aktivitas-aktivitas yang dikontrol secara sistemik oleh birokrasi hanya akan melahirkan rutinitas seremonial belaka, yakni para guru "terlihat" mengembangkan kompetensinya dengan mengikuti berbagai kegiatan pendidikan seperti seminar-seminar dan lain sebagainya tetapi ternyata kegiatan tersebut dilakukan demi memenuhi tuntutan birokrasi agar menjadi guru yang "tersertifikasi". Dan jika sudah tercapai maka tidak ada perubahan yang dalam kompetensi karena hal tersebut hanya bersifat seremonial. Parahnya demi memenuhi tuntutan birokrasi tersebut, aktivitas belajar mengajar yang menjadi inti dari pendidikan sering kali terabaikan. Dari sekian banyak faktor yang mendegradasi dunia pendidikan di bawah rezim birokrasi tersebut, menurut Alhamuddin (2014:56) political will pemerintah dan paradigma politiklah yang memberikan pengaruh paling kuat dalam perubahan-pengembangan, maupun penyempurnaan kurikulum dari masa ke masa.

Lebih lanjut, sektor pendidikan harus dilihat secara berbeda dengan sektor yang lain. Pendidikan adalah aset, modal pembangunan yang sangat besar. Ketika pendidikan diposisikan sebagai modal, maka hasil proses pendidikan tidak dapat langsung dirasakan, perlu waktu puluhan tahun untuk menuai hasil dari proses pendidikan ini. Pemerintah menurut hemat penulis sebenarnya memiliki kekuatan untuk memotong garis birokrasi yang selama ini membelenggu dunia pendidikan. Artinya, jika ada kemauan politik yang baik dari pemerintah ditingkat lokal hingga nasional untuk mereduksi belenggu-belenggu birokrasi dalam dunia pendidikan yang menghambat lahirnya kreativitas agar mutu pendidikan meningkat. Mutu yang dimaksud adalah lahirnya peserta didik yang berkarakter dan berdaya saing, bukan mutu yang hanya tergambar dari angka-angka statistik atau yang bersifat administratif.

Aspek sosiologis masyarakat Indonesia yang sangat plural baik secara vertikal maupun horizontal juga harus menjadi perhatian. Budaya yang terkait erat dengan masalah mentalitas sebagian besar pendidik, peserta didik dan masyarakat yang lebih menyukai budaya instan hendaknya dicarikan solusi konkretnya. Karena budaya yang lebih mendahulukan tujuan daripada proses mencapai tujuan telah melahirkan mentalitas yang serba instan, "yang penting dapat nilai baik, dapat ijazah dan lulus". 
Mentalitas inilah harus menjadi bahan pemikiran karena mentalitas telah "dilegitimasi" bertahun-tahun lamanya oleh kebijakan birokratis pemerintah dalam berbagai bentuk asesment lebih banyak terpaku pada hasil bukan pada proses. Karena pendidikan adalah sebuah proses. Satu hal yang juga tidak dapat dilupakan adalah political will dari pembuat kebijakan, terutama oleh pemangku kebijakan dari level terendah yang ada di sekolah. Menurut Martono (2010), janganlah sebuah kebijakan hanya dijadikan alat untuk meraih kepentingan sekelompok orang saja

\section{KESIMPULAN}

Pendidikan Indonesia saat ini mengalami masa kritis dimana output dunia pendidikan tidak mampu berhadapan dengan dunia yang sesungguhnya, minim skill dan berdaya saing rendah. Salah satu penyebabnya adalah penyelenggaraan pendidikan yang terjebak dalam "kerangkeng besi" birokrasi yang membelenggu dan menghambat proses pendidikan itu sendiri. Dunia pendidikan kehilangan orientasinya, yang ada hanya rutinitas seremonial dan administratif demi memenuhi tuntutan birokrasi dengan segudang peraturan. Aktivitas-aktivitas yang terjadi dalam dunia pendidikan dikontrol secara sistemik oleh birokrasi yang kemudian membuat para guru "terlihat" sedang mengembangkan kompetensinya, padahal mereka hanya memenuhi tuntutan birokrasi itu. Padahal, guru harusnya menjadi pendidik progresif yang koheren, dimana proses belajar atau pengajaran selalu diasosiasikan dengan pembacaan kritis terhadap realitas. Dengan pengajaran itu, guru mengajar bagaimana cara berpikir, bukan terjebak pada kerangkeng besi birokrasi hingga kehilangan "identitasnya" sebagai guru.

Weber memercayai bahwa birokrasi merupakan cara yang efisien dan paling rasional untuk menciptakan keteraturan masyarakat, tetapi di sisi lain ia melihat bahwa praktik dari birokrasi bisa berakhir pada suatu keterjebakan. Sudah saatnya dunia pendidikan keluar dari jerat birokrasi itu, tetapi bukan dalam pengertian tanpa birokrasi sama sekali. Segala aspek administratif yang membelenggu harus direduksi sedemikian rupa agar kehadiran birokrasi kembali pada fungsi utamanya sebagai sarana pencapaian tujuan. Aktivitas pendidikan harus kembali fokus pada praktik inti dari penyelenggaraan pendidikan berupa transfer of knowledge and knowledge sharing. Sebagai kata penutup, "birokrasi adalah hasil kreasi manusia, maka sudah seharusnya birokrasi tunduk pada kehendak manusia bukan manusia yang tunduk pada kehendak birokrasi". Berikan penjelasan yang jelas dan saran terkait hasil temuan riset yang telah dilakukan.

\section{DAFTAR PUSTAKA}

Afriantoni. (2013). Nuansa Politisasi Dalam Pelaksanaan Tugas Guru Sebagai Dampak Dari Desentralisasi Pendidikan. Ta'dib, 18(2), 270-293.

Alhamuddin. (2014). Sejarah Kurikulum Di Indonesia (Studi Analisis Kebijakan Pengembangan Kurikulum). Nur El-Islam, 1(2), 48-58.

Bagaskara, A. (2016). Kerangkeng Besi Di Era Birokratisasi Total. MASYARAKAT: Jurnal Sosiologi, 20(1), 99-102.

Creswell, J. W. (2009). Research Design: Qualitative, Quantitative and Mixed Approaches (Edisi 3). SAGE Publications.

Fauzie, Y. Y. (2018). Bank Dunia: Kualitas Pendidikan Indonesia Masih Rendah. Cnnindonesia. https://www.cnnindonesia.com/gaya-hidup/20180607113429-284304214/bank-dunia-kualitas-pendidikan-indonesia-masih-rendah

Fitrah, M., \& Luthfiyah. (2018). Metodologi Penelitian: Penelitian Kualitatif, Tindakan Kelas \& Studi Kasus. CV Jejak. 
Gay, P. Du. (2005). The Values of Bureaucracy.

Greenwood, R., \& Lawrence, T. B. (2005). The Iron cage in the Information Age: The Legacy and Relevance of Max Weber for Organization Studies. Organization Studies, 26(4), 493-499.

Hadijaya, Y. (2012). Administrasi Pendidikan. Perdana Publishing.

Hariandja, D. B. C. (1999). Birokrasi Nan Pongah: Belajar Dari Kegagalan Orde Baru. Kanisius.

Hasnah. (2012). Paradigma Pendidikan Masa Depan. Jurnal Publikasi Pendidikan, 2(2), $130-138$.

Lase, D. (2019). Pendidikan Di Era Revolusi Industri 4.0. Jurnal Sundermann, 1(1), 2843.

Martono, N. (2010). Refleksi Pendidikan Nasional: Sebuah Upaya Memaknai Kembali Hakikat Pendidikan.

Masduki, M. (2012). Oreintasi Humanisme Pendidikan Islam. Jurnal Madania, 2(1), 6991.

Masniyah, I. (2018). Apliklasi Teori Birokrasi Dan Patologi Max Weber Pada Pemerintahan Desa Kerangkulon Wonosalam Demak. UIN Walisongo.

Ritonga, A. A., \& Basri, M. (2016). Potret Buram Pendidikan Nasional. TAZKIYA, 5(1), 53-80.

Setiyono, B. (2012). Birokrasi Dalam Perspektif Politik Dan Administrasi. Nuansa Cendikia.

Solihin, M. (2015). Kapitalisme Pendidikan (Analisis Dampaknya Terhadap Upaya Mencerdaskan Kehidupan Bangsa). Nur El-Islam, 2(2), 56-73.

Suwarno. (2008). Birokrasi Indonesia: Perspektif Teoritik Dan Pengalaman Empirik. Unisia, 31(69), 254-261.

Syaiful, A. (2018). Politik Pendidikan Islam Masa Reformasi. AL-IMAN: Jurnal Keislaman Dan Kemasyarakatan, 2(1), 134-154.

Syambudi, I. (2019). Anggaran Pendidikan 2019 Naik Rp48,4 Triliun. Tirto.Id. https://tirto.id/anggaran-pendidikan-2019-naik-rp484-triliun-dbFJ

Tekin, S. (2017). Max Weber's Conception of "Iron cage" in Today's Rationality.

Yuksel, A. H. (2014). Visiting the Iron cage: Bureaucracy and the Contemporary Workplace. Springer International, 207-330. 